\title{
Óvó nénik és óvó bácsik - ahogyan a gyerekek látják őket
}

\author{
Járai Krisztina \\ ELTE-TÓK óvodapedagógus/ELTE-PPK neveléstudományi bölcsész, \\ GEM Kognitív Klinika kognitív terapeuta
}

\begin{abstract}
A szakirodalomban számos pedagóguskutatás ismert, rengeteg tanulmány foglalkozott már a pedagógusi szerepkörrel. Ezen munkák összességében három csomópont mentén vizsgálták/vizsgálják a pedagógusi szerepet. A kutatások - időrendi sorrendjüket tekintve - kezdetben a pedagógusok személyiségét vizsgálták különböző tulajdonságlisták felállitásával. Ezt követően a hangsúly a pedagógusok gyakorlati tevékenységének elemzésére került át, majd a pedagógusok tudásának rendszerben való tanulmányozása helyeződött a középpontba (Sántha, 2006). A három föbb kutatási irány természetesen egyidejüleg is jelen van a szakirodalomban, azonban túlnyomó többségük kizárólag a tanári munkát és annak hatékonyságát vizsgálja. Az óvodapedagógusokkal foglalkozó kutatások amellett, hogy lényegesen kisebb arányban képviseltetik magukat, általában az óvodáskorú gyermekek kutatásba való bevonása nélkül készülnek, holott rendkívül érdekes és nem kevésbé fontos kérdés lehet az, hogy vajon maguk az óvodások kit tartanak ,jó" pedagógusnak. Jelen tanulmányban - mely Az óvodapedagógusi szerep címü szakdolgozat rövidített kivonataként készült - a pedagógusi szerepkörre, illetve a pedagógusok nemére vonatkozó elméleti áttekintést követően arra teszünk kísérletet, hogy az óvodáskorú gyermekek óvodapedagógusokról alkotott képének feltárását célzó kutatás föbb eredményeit ismertessük, kiemelt figyelmet fordítva arra, miként tesznek különbséget az óvodások a női és férfi óvodapedagógusok között.
\end{abstract}

Kulcsszavak: pedagóguskompetenciák, óvodapedagógus, pedagóguskép, nemi különbségek, kutatás

\section{Elméleti háttér}

\section{Az óvodapedagógusi szerep - személyiségjegyek és kompetenciák}

AXXI. században pedagógusnak lenni nem egyszerű dolog. A pedagógusokkal szemben támasztott igények, ahogyan a társadalmi berendezkedés is, megváltoztak. $A$ napjainkban egymás mellett jelenlévő alternatív nevelési irányzatok többféle pedagógusképet rajzolnak meg egyidejüleg, ahogyan az elvárt, egymástól különböző pedagógusszerepek is egyszerre vannak jelen (Fehér, 2003). Ez azt eredményezi, hogy nehéz megrajzolni napjaink ideális pedagógusát, a szakirodalomban rendelkezésünkre álló pedagóguskutatások eredményeinek közös tartalmi elemei ugyanakkor mégis elénk tárják a pedagógusok ideáljának mondható tökéletes gyermeknevelőt (Hegyi, 1996).

Az óvodapedagógusi szerep folyamatos változásokon ment keresztül az első óvodák megalakulása óta. Napjainkban a pedagógusok szolgáltató szerepe kezd egyre dominánsabbá válni. Pedagógusaink már nemcsak az óvodáskorú gyermekek felügyeletét és nevelését látják el, de egyidejüleg kell betölteniük számos egyéb funkciót is. Kiszélesedett feladatkörüket elsősorban az óvoda társadalmon belül betöltött szerepének megváltozása indokolja, az óvoda intézménye ugyanis egyre inkább a családi nevelés kiegészítője, az ott folyó nevelés korrekciós, hiánypótló szervezeteként van jelen. Ezzel összefüggésben a pedagógusok egyszerre töltenek be személyiségfor- 
máló, ismeretátadó, szocializációs, zavarfelismerő és helyrehozó, szűrő-diagnosztizáló és családgondozó szerepet (Fehér, 2003).

Az egyes, egymástól némiképp különböző szerepkörök közös eleme, hogy a pedagógusi munkát az ún. segítő foglalkozások közé helyezi. A segítő szerepkör a pedagógusoknál Rogers szerint három személyiségbeli tulajdonság: az empátia, a feltétel nélküli elfogadás és a kongruencia meglétét feltételezi (Fehér, 2000).

Noha a szakirodalomban megannyi a pedagógusi szerepkörrel és az ahhoz nélkülözhetetlen kompetenciákkal foglalkozó tanulmány van jelen - melyek túlnyomó része a tanítók, még inkább pedig a tanárok oldaláról közelít -, a pedagógusi képességekkel foglalkozó szakemberek többé-kevésbé hasonló képességek meglétét tartják fontosnak a pedagógusi, óvodapedagógusi szerep esetében.

A pedagógiai képességek vizsgálatakor olya sokszor idézett Hegyi Ildikó által kidolgozott képességrendszer különbséget tesz az ún. alapképességek - melyek egyszerre járulnak hozzá többféle tevékenység hatékony végzéséhez és az általános egyéni sikerességhez -, illetve a sajátos képességegyüttesek - melyek az alapképességekkel ellentétben különböző, speciális területeken végzett tevékenységek eredményességéhez járulnak hozzá - között. Hegyi modelljében a pedagógiai képességeket a sajátos képességegyüttesek egyik csoportjaként értelmezi, s különbséget tesz általános és speciális pedagógiai képességek között. A modellben az általános képességek a speciális képességek alapját jelentik, hiányuk képes lehetetlenné tenni a hatékony pedagógiai munkát.

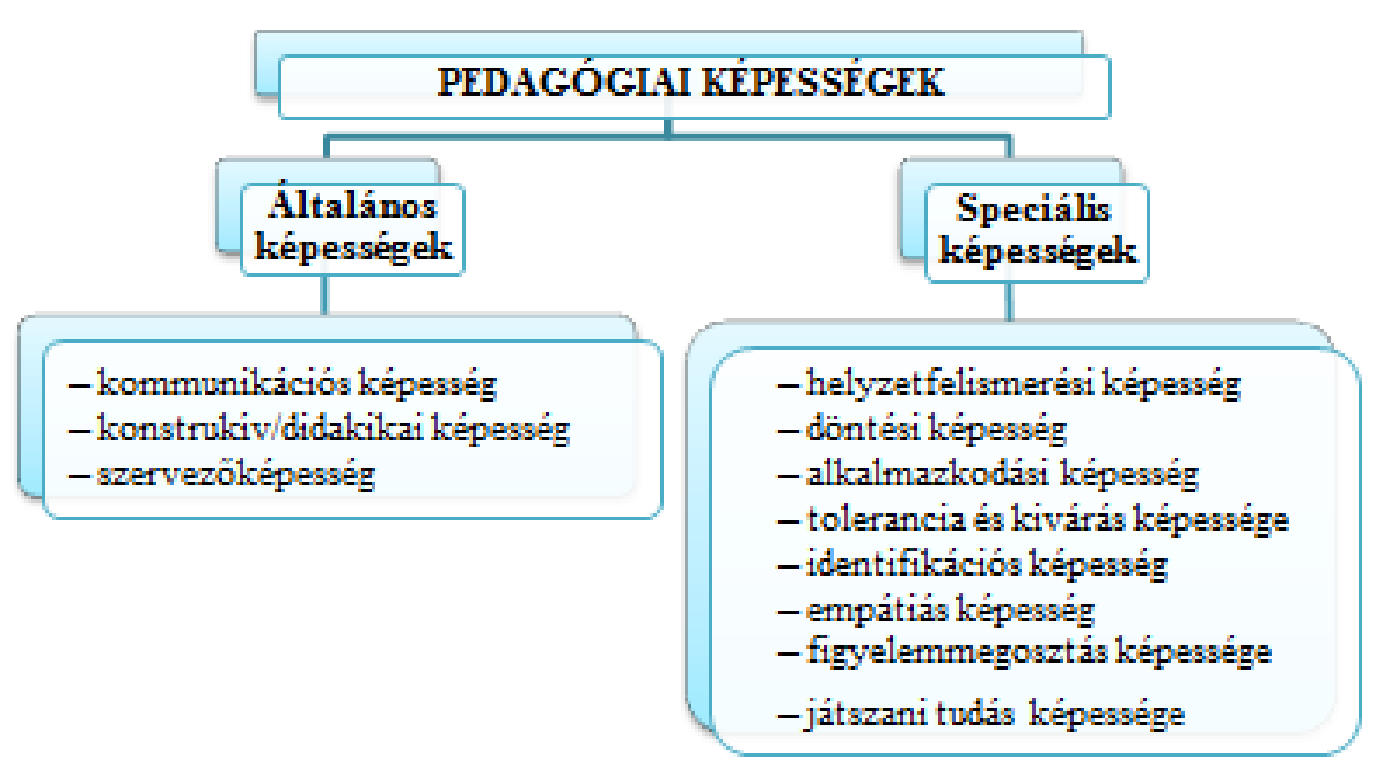

1. ábra: A pedagógiai képességek összetevői, Hegyi lldikó tanulmányai nyomán

„A kommunikációs képesség a kapcsolatteremtés, a kapcsolatfelvétel és -megtartás, valamint a szerepvállalással szorosan megjelenö társas együttmüködés képessége" (Hegyi, 1996, 39.o.). Színvonalára nagy hatással van az egyén szociális intelligenciájának szintje. Az óvodában folyó nevelői munka során a jó pedagógus képes megtalálni a gyermekekhez illő hangnemet és közlési stílust, mondanivalóját minden esetben pontosan és érthetően fejezi ki. A verbális és nonverbális - mimika, pantomimika, proxémika - közlési módokat egyaránt ismeri és alkalmazza. Az ideális pedagógus képes saját impulzivitását kordában tartani, és ügyel arra, hogy esetleges 
negatív érzelmeit a gyerekek elöl bizonyos mértékben elrejtse, hiszen az óvodáskorú gyermekek kiemelkedő érzékenységet tanúsítanak nemcsak a másik ember érzéseinek, hangulatának átvételében, de az arcokra kiülö érzelmek gyors értelmezésében is. A gyakori negatív érzelmek pedig károsan hathatnak a személyiségfejlödésre (Hegyi, 1996; Jávorné, 2004).

„A konstruktív, vagy didaktikai képesség az ismeretszerzési folyamatban, az oktatni tudásban nyilvánul meg" (Hegyi, 1996. 40. o.). Az óvodákban, ahol a szervezett tevékenységekben való részvétel a gyermekek számára önkéntes, különösen fontos szerepe van a motivációnak. A jó óvodapedagógus a gyermekek figyelmét nemcsak felkelteni, de fenntartani is képes, az új ismereteket pedig a gyermekek számára is könnyen érthetően adja át.

A szervezőképesség a teljes óvodai nevelői munka sikerességének zálogaként is értelmezhető. Az ideális óvodapedagógus jó idő és téri tájékozódással, áttekintőképességgel és strukturált gondolkodásmóddal rendelkezik, melyek nemcsak a gyermekek napi tevékenységeinek gondos és következetes megtervezésében, de a szülökkel, kollégákkal való kapcsolattartásban is segítik őt (Jávorné, 2004).

A speciális pedagógiai képességeket az alkalmazásukkor adódó nevelési helyzetek teszik különlegessé. $E$ képességek tulajdonképpen csak egymást kiegészítve léteznek, és szorosan összefüggenek (Hegyi, 1996).

A helyzetfelismerési és döntési képesség szinte feltételezi egymás jelenlétét. Mint ismeretes, egy pedagógus munkája során gyakran kerül olyan döntési helyzetekbe, amelyekben az adott szituációt felmérve, a lehető leggyorsabb időn belül kell döntenie. Ezen helyzetek olyan reális helyzetfelismerést és adekvát döntést kívánnak meg - a lehető legpozitívabb kimenetel érdekében -, melyekre a jó pedagógus képes.

Az alkalmazkodás, a tolerancia, az identifikációs képesség és az empátia képessége szintén összefüggnek egymással. Munkája során a pedagógus különböző személyiségü, képességü, külsejü, vallási, és etnikai hovatartozású gyermekkel találkozik, hozzáállásában azonban nem szabad különbséget tennie közöttük. Az óvodapedagógus is ember, így természetes, hogy nem egyenlő mértékben érez rokonszenvet minden gyermek iránt, ugyanakkor a jó pedagóguson ez nem látszik. Képes a gyermekek egyéni és életkori sajátosságainak figyelembevételével differenciált nevelést folytatni, és minden gyermekben a szerethetőt meglátni. Képes továbbá beleképzelni magát mások helyzetébe és azonosulni azzal.

A figyelemmegosztás képessége véleményem szerint az egyik legfontosabb pedagógiai képesség. A szakirodalom szerint a figyelemmegosztás egyike a legnehezebben fejleszthető képességeknek, hiánya a pedagógiai munka során tapasztalt folyamatos kudarcokat eredményezi. Az óvodapedagógusoknak más pedagógusi csoportokhoz képest nehezebb helyzetük van a magas gyermeklétszám és az egymással párhuzamosan folyó tevékenységek miatt, azonban egy jó óvodapedagógus képes átlátni a teret.

A játszani tudás képességének szükségessége nem kérdőjelezhető meg, amikor a jó óvodapedagógus jellemzőit gyűjtjük össze. A játék minden kisgyermek elemi, pszichikus szükséglete, az óvodai nevelés leghatékonyabb eszköze és leghangsúlyosabb cselekvési formája. Fontosságával és természetével számos kutatás és tanulmány foglalkozott már. A nevelői játszóképesség valójában egyfajta képességcsoportként értelmezhető, mely több - korábban is említett - képesség együttes meglétét feltételezi. A magas szintű játszóképességgel rendelkező óvodapedagógus személyiségét a humor, a tolerancia, a széleskörü érdeklődés, a magas gyakorlati intelligencia, az aktivitás igénye és a gyermekek utáni vágyakozás jellemzi (Kovácsné, 2008). 
Egy másik, Hegyi Ildikó megközelítésétöl némiképp eltérő, ugyanakkor sok tekintetben ahhoz hasonló modellt állított fel - a pedagógiai képességek vizsgálatával foglalkozók által szintén sokat emlegetett - Sallai Éva. Sallai modelljében nemcsak személyiségjegyeket és képességeket sorakoztat fel, hanem olyan tényezőket, tartalmi elemeket rendez sorba, melyek a pedagógusmesterség eredményes gyakorlásához egyaránt szükségesek.

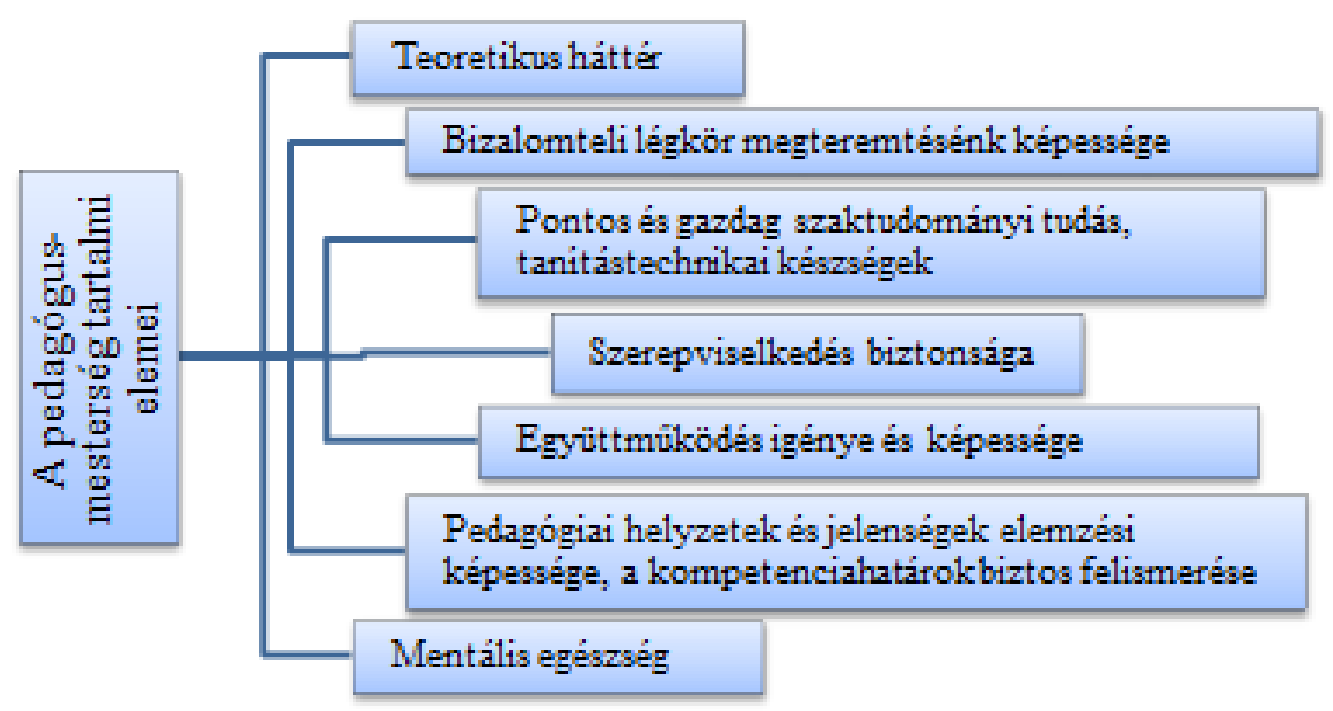

2. ábra: A pedagógusmesterség tartalmi elemei Sallai Éva meghatározásában

A teoretikus háttér a pedagógusok által magukban összerendezett ismeretek öszszességét takarja „,a világról, az emberről, az ember fejlődéséröl, a tanulásról és mindezek segítéséről” (Sallai, 1996).

Bizalomteli légkörben az iskolások könnyebben és gyorsabban képesek tanulni, magasabb önértékeléssel bírnak. Nincs ez máshogy az óvodában sem, ahol a bizalomteli légkör szintén a hatékony nevelés alapvető feltételeként jelenik meg. A gyermekek ilyen közegben bátrabbá és aktívabbá válnak, a megtorlás nélküli hibázás lehetősége, $\mathrm{s}$ a pedagógus gyermekszeretete növeli a teljesítményszintet, és pozitívan hat a társas kapcsolatokra is. A bizalomteli légkör megteremtésének képessége feltételezi a pedagógus részéröl a gyermekek feltétel nélküli elfogadását, a korábban már említett empátiát, illetve a kongruenciát (Sallai, 1996). A pedagógus hitelessége természetesen nemcsak a kedvező légkör kialakításában játszik szerepet, de az egész nevelői munka hatékonyságát átszövi.

A szaktudományi szempontból gazdag tudás a jó tanártól megfelelő szintű elméleti ismereteket vár el, mind az adott szaktárgy pontos ismeretét, mind pedig a gyermekek pszichológiai jellemzőit és a pedagógia módszertanát illetően. A tanítástechnikai készségek az adott tárgy eredményes tanítását lehetővé tévő módszertári gazdagságot jelentik. Az óvodapedagógusokra vonatkoztatva mindezek a hatékony óvodai neveléshez szükséges lélektani, módszertani és tudományos ismeretek meglétét, s azok egyéni és életkori sajátosságokat figyelembevevő alkalmazását jelölhetik.

A szerepviselkedés során érzett biztonság nagyban befolyásolja a pedagógiai munka hatékonyságát. A jó pedagógus reális önismerettel rendelkezik, erősségeire támaszkodva és gyengeségeit tudatosan fejlesztve igyekszik szakmájában minél kompetensebbé válni. „A szerepviselkedés biztonságáról akkor beszélünk, ha a személyiség adott szerephelyzetekhez szükséges eszközrendszere megvan, és a pedagógus 
maga is jónak itéli meg a saját kompetenciáját” (Sallai, 1996, 46. o.). Ahhoz, hogy a pedagógus, jelen esetben az óvodapedagógus kellő biztonságban érezze magát, azaz munkája során ne szorongjon, s ne féljen attól, hogy nevetségessé válik, szüksége van bizonyos képességek meglétére, úgy, mint:

- „kommunikációs ügyesség

- rugalmas és gazdag viselkedésrepertoár

- gyors helyzetfelismerés, konstruktív helyzetalakítás

- erőszakmentes, kreatív konfliktusmegoldás”(Sallai, 1996. 21. o.).

Az együttmüködés igénye és képessége az iskolában tanítók számára azért elengedhetetlen, mert az iskolában egyfajta csapatmunka folyik. Nincs ez másképp az óvoda intézményét és az ott zajló nevelői munkát tekintve sem. Az óvodai nevelés a családi nevelés kiegészítőjeként, csak a családdal együttműködve mehet végbe. Ahhoz azonban, hogy az óvodapedagógus a családdal egyenrangú, jó kapcsolatot tudjon kialakítani és fenntartani, a korábban említett képességeken túl - úgy, mint empátia, tolerancia, szervezőképesség stb. - magas fokú együttmüködő-képességre is szüksége van, ahogyan nélkülözhetetlen e képesség a gyerekekkel és a kollégákkal való közös munka során is.

A pedagógiai helyzetek és jelenségek elemzésével a pedagógusok saját tapasztalataik által válnak képessé tanulni és fejlődni (Sallai, 1996). „A pedagógiai munka során ki kell alakulnia azoknak az elemzési szokásoknak, amelyek emelni tudják a tudatosság szintjét, hiszen így válik az eredményes pedagógiai munka megismételhetővé" (Sallai, 1996. 68. o.).

A pedagógus mentális egészsége az eddig felsoroltak közül talán a leginkább befolyásolja mindennapi munkavégzésének minőségét, hiszen a pedagógus legfontosabb munkaeszköze a személyisége. A pedagógusok mentálhigiénéjével a szakirodalom külön egységként foglalkozik, jelen tanulmányban elegendő lehet annyit megemlíteni róla, hogy a lélek egészsége nélkül nem létezhet hatékony pedagógiai munka.

Az előbbiekben ismertetett két képességmodell kellemes szintézisét alkotja a szakirodalomban fellelhető hazai és külföldi pedagógusi képességmodelleknek egyaránt. A jelen tanulmányban nem idézett más írások olyan személyiségjegyek említésével egészítik ki az előbbiekben ismertetett két modellt, mint a humor, az őszinteség, a kreativitás és a felelősségvállalás. Természetesen ezen tulajdonságok és kompetenciák feltételezik és kiegészítik a már említetteket, hiszen a pedagógus kongruenciája együtt jár az őszinteséggel, a jó konfliktuskezelő és a váratlan helyzetek megoldására irányuló képesség kreativitást feltételez, a jó kommunikációs képesség magában foglalja a humor megfelelő használatát, és a gyermekek feltétel nélküli elfogadása lehetővé teszi a felelősségvállalást.

A pedagógusi kompetenciák és nézetek, valamint a gyakorlati munka színvonala szoros kapcsolatban állnak egymással. „A pedagógus pszichikus rendszerében jelenlévő nézetek mögött a szakmai identitás, énkép és elhivatottság mintegy alapként határozzák meg a pedagógus kompetenciáit, és ez utóbbi közvetlen befolyást gyakorol a pedagógus szakmai tevékenységére" (Fábián, 2011. 13. o.).

Az előbbiekben ismertetett képességmodelleket összehasonlítva az óvodai nevelést alapjaiban meghatározó dokumentumokban - Köznevelési Törvény, Óvodai Nevelés Országos Alapprogramja, Pedagógusi Életpályamodell, Pedagógusok Szakmai Etikai Kódexe - kirajzolódó pedagógusképpel rengeteg egyezést fellelhetünk; az ideális pedagógustól elvárt személyiségjegyek és kompetenciák nagy hangsúllyal tükröződnek az óvodák működését szabályozó, és személyi feltételeit megszabó dokumentumokban. 


\section{Az óvodapedagógus neme}

Az óvodáskorú gyermekek nevelését nőkre bízni már az első hazai óvodát alapító Brunszvik Teréznek is eszébe jutott, aki Mikó utcai óvodájának megnyitásakor már azt tervezte, hogy 1829-től nőkre bízza a gyermekek nevelését. Ennek érdekében 11 fiatal lányt vett maga mellé és kezdett tanítani, de korabeli források szerint intézményében a kor elvárásainak megfelelően férfiakat alkalmazott (Zibolen, 1984).

A szabadságharcot követő megtorló időszakban több képző is alakult, ahogyan tanfolyamok is szerveződtek a Fröbel-féle pedagógia hazai átültetésének céljából. Fröbel, Montessorihoz hasonlóan úgy gondolta, nőkre van szükség az óvodákban folyó nevelői munkának, ennek okán kizárólag "gyermekkertésznőket” kívánt a gyermekkertekbe (Kraffszky, 1993). Eötvös József 1870-ben közzétett, 1874/75-ös tanévben érvénybe lépő törvényjavaslata szintén be kívánta vonni a nőket a kisdedóvó szerepbe. Javaslata szerint az addig egyéves óvóképzés időtartamát szükséges kétévesre bővíteni, a képzőket pedig nők és férfiak számára egyaránt megnyitni (Kövér, 1996). Eötvös rendeletétől kezdődően egyre több nő lépett óvodapedagógusi pályára, és lassan megkezdődött az elnőiesedés folyamata, noha az 1937-ben Tolnán megnyíló - majd a fővárosba költöző és 1944-től Ney Ferenc irányításával müködő - első magyar óvóképző is elsősorban férfi óvójelöltek számára nyitotta meg kapuit Wargha István vezetésével.

Az óvodapedagógusi pályát napjainkban jellemző erős elnőiesedés okát a pedagógusi pálya alacsony társadalmi presztízsében, valamint a nemi szerepekhez tartozó sztereotípiákban egyaránt kereshetjük. A nemi sztereotípiák személyiségvonásokat, kognitív jellemzőket, szerepelvárásokat, valamint vélt külső jellemzőket tartalmaznak, melyek egyfajta legitimációs funkcióval bírnak, azaz a különböző sztereotipizált csoportok által is elfogadottá teszik a rájuk vonatkozó pozitív vagy negatív sztereotípiákat. Ezek szerint „a férfiak dominánsak... függetlenek... versengők, agresszívek... érdekli őket az üzlet, a sport és a politika. A nők... érzékenyek mások igényeire, törődőek, hajlandóak másoknak szentelni magukat, jók a házimunkában és a gyermekgondozásban" (Kovács, 2007. 101. o.). Noha a társadalmi rendszer stabilitásáért felelös sztereotípiák és a hozzájuk kapcsolódó szerepelvárások kultúránként egymástól eltérőek lehetnek - például Japánban nincsenek női vezetők, míg ezzel egyidejüleg a Fülöp-szigeteken ők vannak többségben - a modern társadalmakban általában a nőkkel szemben támasztott elvárás a gyermeknevelés, mely olyan feminin tulajdonságok meglétét idézi, mint a gondoskodás, érzelmesség, empátia, hiszékenység (Kovács, 2011).

Az előbbiek ismeretében nem csoda, ha kevés férfi választja a meglehetősen feminin jellegűként sztereotipizált óvodapedagógusi pályát. Az óvók képzésével foglalkozó intézmények sem veszik kellően figyelembe azt a néhány elhivatott óvó bácsi jelöltet, akiket hallgatóik között tarthatnak számon. Az óvóképzésben jelenleg is tankönyvként használt pszichológiai írások szinte egyöntetúen az anya-gyermek kapcsolat fontosságát hangsúlyozzák, azt a tudatot erősítve, hogy a gyermekek nevelésére az óvodában is inkább a nők alkalmasak (Perlai, 2009), ahogyan az óvodapedagógusokkal foglalkozó néhány kutatás is elsősorban az óvónőket vizsgálja különböző szempontok szerint. De vajon tényleg nincs szükség férfiakra az óvodai nevelés során?

A szakemberek elsősorban a férfimodell hiányát tartják a pedagóguspálya elnőiesedésével kapcsolatos legnagyobb hátránynak, kiváltképp napjainkban, amikor egyre több a válás, s egyre gyakoribb azon csonka családok száma, melyekben azt 
láthatjuk, hogy a gyermek nevelésében nem vesz részt az apa, noha köztudott, hogy az apának puszta jelenléte is kiemelt fontossággal bír a gyermekek életének első éveiben (Winnicott, 2000). Az óvodában dolgozó férfiak ugyanakkor amellett, hogy modellt nyújtanak a férfias viselkedésre, más területeken is az óvónőkhöz képest eltérő mintákat állíthatnak a gyermekek elé.

Természetes, hogy a férfiak más módon gondoskodnak óvodásaikról, más konfliktuskezelő stratégiákra tanítják a gyerekeket, ahogyan férfiasságukból adódóan képesek olyan tevékenységformákat is megismertetni a gyermekekkel, melyek egy óvónőtől esetleg távol állnak. A nemi identitás kialakulását segítő és számos egyéb fejlesztő hatással bíró csocsózásra, vagy gombfocizásra feltehetően kevés óvónő vállalkozik, míg a férfi óvodapedagógusok szívesen építik be azokat nevelői munkájukba. A férfiakra jellemző sajátos kommunikációnak köszönhetően az óvó bácsiktól másféle kommunikációs mintákat sajátíthatnak el a gyerekek, de más lesz a kommunikáció jellege szülő és pedagógus között is. Összességében elmondhatjuk tehát, hogy bár hazánkban az óvó bácsik száma sajnos elenyésző, a férfiak nemcsak színesebbé tehetik az óvodáskorú gyermekek mindennapjait, de az óvónők munkájával kiegészülve, azzal egységet alkotva az óvodáskorú gyermekek komplexebb személyiség-, készség- és képességfejlődéséhez járulhatnak hozzá.

\section{Az empirikus vizsgálat jellemzői}

\section{Célok és hipotézisek}

Bár a szakirodalom bővelkedik pedagóguskutatásokban, az óvodások átfogó pedagógusképének vizsgálata ez idáig meglehetősen háttérbe szorult. Kutatásunk elsősorban azon kérdésekre keresi a választ, hogy mi van az óvodások fejében az óvodával és a bennük dolgozó pedagógusokkal kapcsolatban. Kit tartanak ők ideális pedagógusnak, illetve milyen tényezők mentén jellemeznek egy kevésbé jó óvodapedagógust. Mindezek mellett kíváncsiak vagyunk arra is, mit gondolnak a gyermekek a férfi és női óvodapedagógusokról, különbséget tesznek-e közöttük, és ha igen, miben tartják őket egymástól eltérőnek. Kutatásunkban a gyermekek konkrét - vagyis saját óvodapedagógusaikról személyes élményeiken keresztül kialakult - és általános pedagógusképét, valamint a közöttük fennálló kapcsolatot is feltárni kívánjuk, ahogyan célunk a szakirodalom és a gyermekek által kívánatosként megrajzolt pedagóguskép összehasonlítása is.

Noha kutatásunk elsősorban feltáró jellegü, s a kutatási célok megfogalmazása során felmerülő kutatási kérdésekre keresi a választ, a témával kapcsolatos szakirodalmi tájékozódást figyelembe véve az alábbi néhány hipotézist állítottuk fel:

1. A szakirodalomban megjelenő pedagógusi kompetenciák nagyjából megegyeznek a gyermekek által kedvelt pedagógus személyiségjegyeivel.

2. Az óvodáskorú gyermekek különbséget tesznek a férfi és női óvodapedagógusok között, és az eltéréseket meg is tudják fogalmazni.

3. Az óvodáskorú gyermekek az óvónőkhöz elsősorban azok fizikai tulajdonságai és gondoskodó személyiségjegyei miatt ragaszkodnak, míg a férfi óvodapedagógusok iránti vonzalmaikat inkább a közösen végzett tevékenységek határozzák meg.

4. Azon gyermekek többsége, aki az óvodában csak óvónőkkel találkozik, örülne, ha csoportjában férfi óvodapedagógus is dolgozna. 


\section{Minta}

A kutatás során hat óvodai csoportot látogatunk meg, és összesen hetvennégy, öthét éves gyermeket kérdeztünk meg. A kutatási minta kiválasztásánál szempont volt, hogy azok az óvodák, melyekben a csoportok működnek, ne dolgozzanak semmilyen alternatív vagy egyéb, egymástól eltérő speciális programmal, s a bennük dolgozó óvodapedagógusok életkora nagyjából megegyezzen egymással. Ezzel megegyezően a hat óvodai csoport mindegyike az egészséges életmódra való nevelést közvetíti elsősorban a gyermekek számára, a hat óvodapedagógus közül pedig négy huszonnégy-huszonnyolc, míg kettő negyven-negyvenkét éves kor közötti. A vizsgálat eredményeinek hitelessége szempontjából törekedtünk rá, hogy a négy budapesti és két vidéki csoportban egyenlő arányban kérdezzünk meg gyerekeket óvó nénik és óvó bácsik csoportjából, így a résztvevők közül 37 gyermek jár kizárólag óvónők csoportjába, míg szintén 37 gyermek rendelkezik óvó bácsival is. Végül, de nem utolsó sorban a vizsgálati minta ismertetésekor megemlítendő, hogy a résztvevő gyermekek nemének megoszlásában szintén egyenlőségre törekedtünk, 38 fiút és 36 lányt kérdeztünk meg.

\section{Módszerek}

Kutatásunkban a trianguláció elvének biztosítása, illetve a téma minél mélyebb feltérképezésének céljából három módszert alkalmaztunk. A rajzvizsgálatot - melyen a gyermekek csoportonként együtt vettek részt - egy strukturált interjú, valamint egy metaforavizsgálat követte, melyeket minden résztvevő gyermekkel külön, kétszemélyes helyzetben készítettünk el.

A rajzvizsgálat alapötletét a kinetikus iskolarajz módszere adta. Arra kértük a gyerekeket, rajzolják le magukat és óvodapedagógusukat, miközben valamit közösen csinálnak. A rajzon megjelenített tevékenységnek nem volt feltétele, hogy az valóságos, a múltban már megtörtént legyen, a gyermekek fantáziájukat szabadon engedhették és bármit lerajzolhattak, ami eszükbe jutott.

A 11 kérdésből álló strukturált interjú során 3 kérdés vonatkozott a gyermekek személyes élményeire és tapasztalataira, 8 kérdés pedig az általános óvoda- és pedagógusképüket vizsgálta.

A metaforavizsgálattal - mely során a gyerekeket arról kérdeztük, egy jó tündér milyen állattá varázsolná át saját óvodapedagógusukat - kettős célunk volt. Egyrészről azt reméltük, hogy az esetleg tudatosan meg nem fogalmazott, elnyomott negatív gondolatokat a gyermekek az elvarázsolt állatok tulajdonságaiban könnyebben jeleníthetik meg, másrészről pedig kíváncsiak voltunk arra, vajon mutatkoznak-e eltérések az asszociációkban aszerint, hogy milyen nemü pedagógusról van szó, és ha igen, melyek azok.

\section{Az empirikus vizsgálat eredményei}

\section{A megkérdezett gyermekek kapcsolata saját óvodapedagógusaikkal}

\section{A gyermekrajzokban megjelenő pedagógus-gyermek kapcsolat}

A kutatás során elkészült gyermekrajzok értékelésekor - ahogyan arról már korábban is szóltunk - az ún. kinetikus iskolarajz elemzési szempontjait, valamint az általános 
rajzelemzési szempontokat ötvöztük és vettük figyelembe. Tekintettel arra, hogy kutatási célunk a gyermekek pedagógusképének minél mélyebb feltárására irányult, a rajzok elemzésekor nem volt célunk azok különböző más szempontú, pszichológiai, fejlődéspszichológiai, esetleg diagnosztikus értékelése. Mindezek tudatában az alábbi négy szempont szerint vizsgáltuk meg a gyermekek rajzait:

- a rajz mint egész vizsgálata;

- a rajzon megjelenített tevékenységek;

- az ábrázolt pedagógus külső jegyei;

- a gyermek pedagógushoz füződő érzelmi viszonyulásának jellemzői (színhasználat, hasonlóság, méretarányok) (Tihanyiné, 2008; Vass, 2011).

Összességében elmondható, hogy a mintában szereplő 74 rajz többsége (60) pozitív, vidám hangulatot áraszt, míg 10 rajz semleges, 4 pedig inkább rossz hangulatú. A számadatokat tekintve megállapítható, hogy a megkérdezett gyermekek többsége vidám, harmonikus rajzot készített, ami az óvodapedagógusaikkal való pozitív kapcsolatot feltételezi, a férfi óvodapedagógusokkal készült jó kedélyű rajzok fölénye az óvó bácsik nagyobb népszerüségéről árulkodhat (ld. 1. diagram).

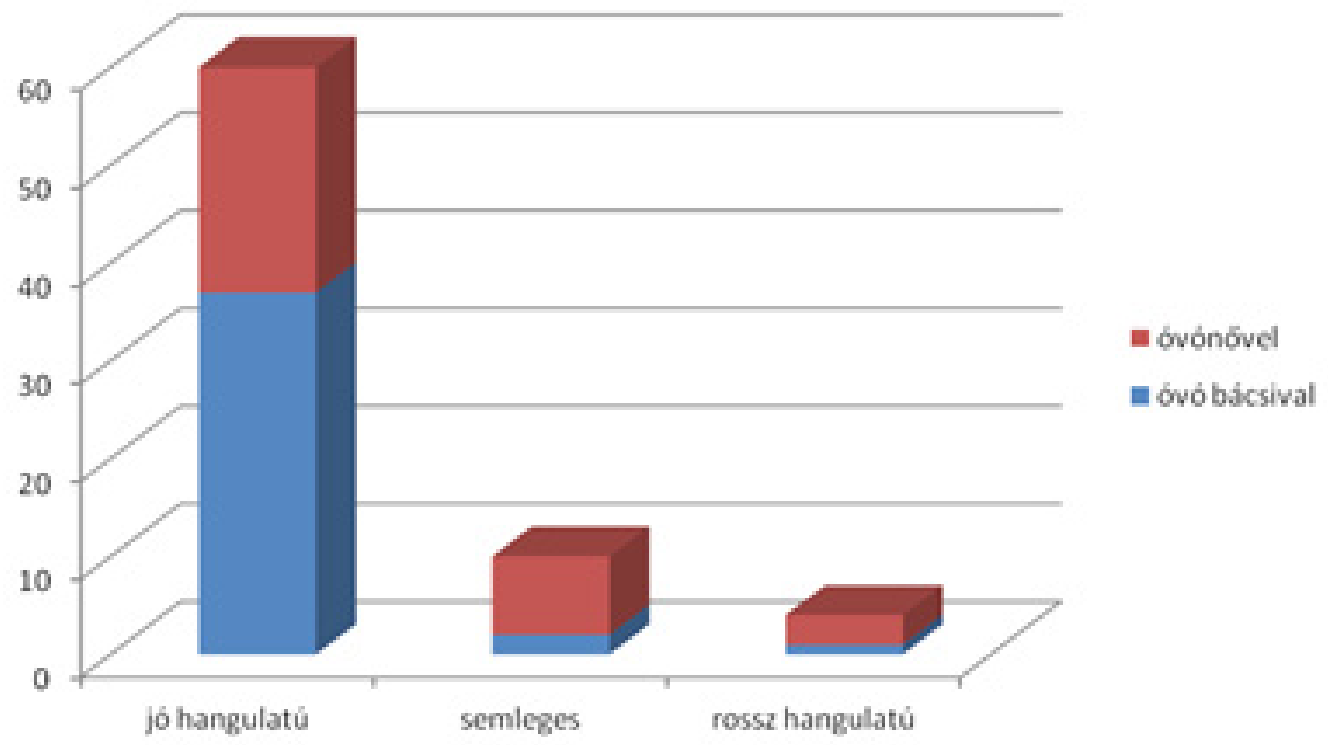

1. diagram: A női és férfi óvodapedagógusokkal készült rajzok hangulatának megoszlása

A rajzokon megjelenített tevékenységek színhelyéül 41 rajz esetében szolgál az óvoda helyett a természet, kiemelten pedig a rét (23), ami arra enged következtetni, hogy egyrészt a gyermekek bíznak annyira pedagógusaikban, hogy az óvoda falain kívül is jól érezzék magukat a társaságukban, másrészt pedig igénylik a természettel való közvetlen kapcsolatot, s jól érzik magukat a szabadban.

Az elkészült rajzok közül 29 esetben jelenik meg az óvoda, vagy annak közvetlen környezete, mint a pedagógussal való együttlét helyszíne. 8 rajz ábrázolja azt, amint a gyermek a pedagógussal együtt érkezik meg az óvodába, 16 rajz a csoportszobán belüli tevékenységekre utal, míg 5 rajz az óvoda udvarát jeleníti meg. Ez arra utalhat, hogy a gyermekek gondolataiban az óvodapedagógus személyisége erősen összekapcsolódik az óvodába járás tényével, illetve az óvoda intézményével. A pedagógusokkal végezhető tevékenységek eszerint az óvodai élet mindennapi eseményeit jelölik, melyeknek a pedagógus aktív és nélkülözhetetlen résztvevője. 


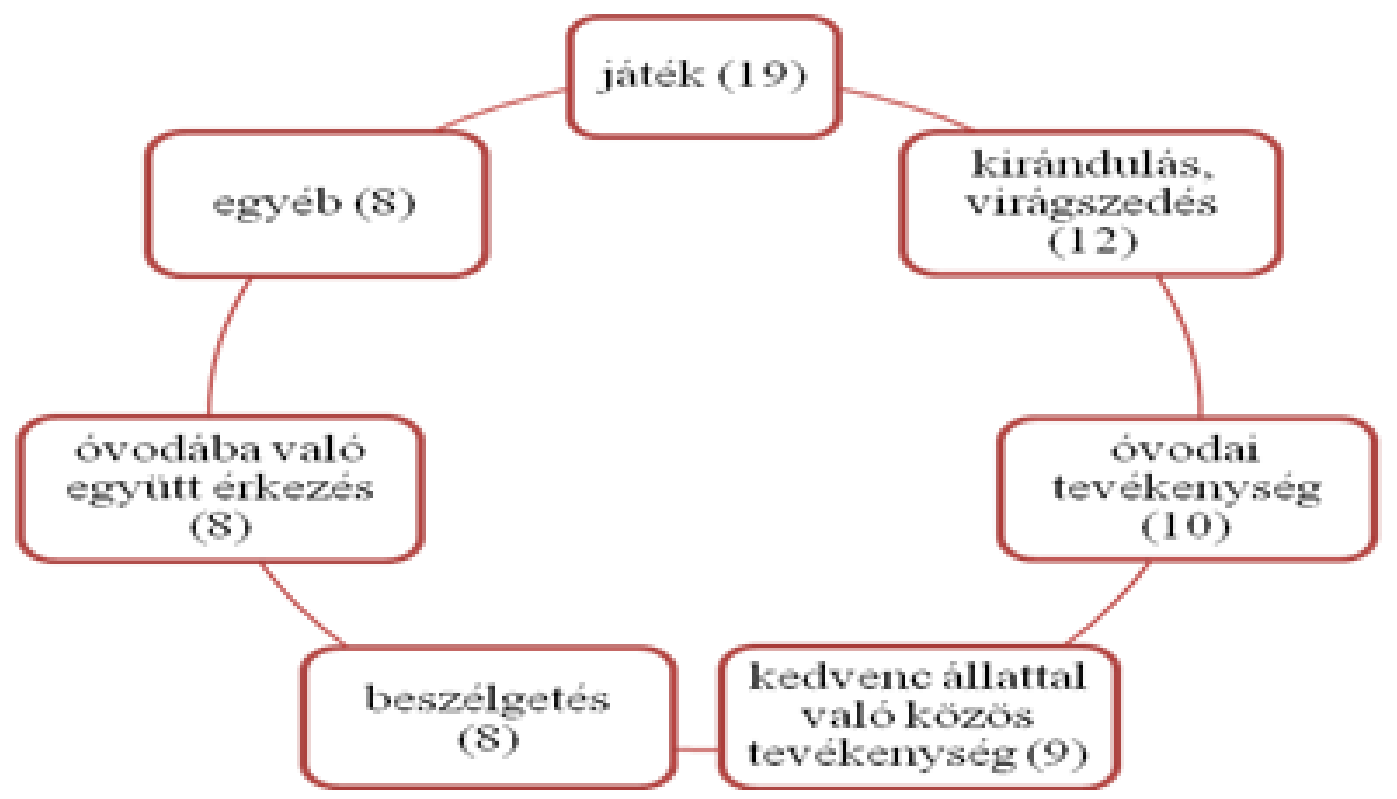

3. ábra: A gyermekek rajzain megjelenített tevékenységek és azok gyakorisága

A rajzokon a pedagógusokkal végzett tevékenységek közül legtöbbször a közös játék jelent meg. Ez talán nem meglepő az óvodáskorúak életkori sajátosságait figyelembe véve, hiszen ebben az életkorban a játéknak kitüntetett szerepe van.

A különböző óvodai tevékenységek - közös evés, különböző foglalkozásokon való részvétel, délutáni pihenőhöz való készülödés - ábrázolása jól összekapcsolódik az óvodának mint a megjelenített események helyszínének korábban említett magas számával, ami azt bizonyítja, hogy a gyermekek pedagógusképéhez hozzátartoznak az óvók intézményen belül betöltött szereprendszerei.

Az óvodába való együtt érkezés megjelenése a pedagógussal való bizalmas kapcsolatra utalhat, a rajzok készítőinek elmondásai alapján ugyanis az óvó nénivel/ óvó bácsival együtt megérkezni sokkal jobb, mint egyedül. Szintén a bensőséges, intim pedagógus-gyermek kapcsolatról tesz tanúbizonyságot a pedagógussal és a kedvenc háziállattal való közös időtöltés - kutyasétáltatás, lovaglás, madáretetés, akváriumnézegetés -, illetve az óvodán kívüli tevékenységek - kirándulás, virágszedés - ábrázolása. Ezek ugyanis arra utalnak, hogy a gyermek szívesen osztja meg örömeit a pedagógussal, $\mathrm{s}$ az óvodán kívüli életébe is beengedi őt. A kirándulás és a természet viszonylag nagyszámú ábrázolását ugyanakkor az előbbieken túl az óvodák szervezett kirándulásainak emlékei is táplálhatják, hiszen a kutatás során felkeresett négy óvoda mindegyike gyakran viszi kirándulni a gyermekeket.

A rajzokon ábrázolt pedagógusok külső jegyeit vizsgálva, szembetűnő különbség figyelhető meg a pedagógusok nemének tekintetében. Míg a gyermekkel azonos nemủ pedagógust megjelenítő rajzokon - különösen a fiúk esetében - pedagógus és gyermek általában nagyon hasonlít egymásra (Id. 4. ábra), addig az ellentétes nemü pedagógus-gyermek párokról készült alkotások gyakran több dimenzió mentén is eltérnek egymástól. Ez a különböző nemi szerepek tanulására és a saját nemi szereppel való azonosulást célzó törekvésre utalhat. 


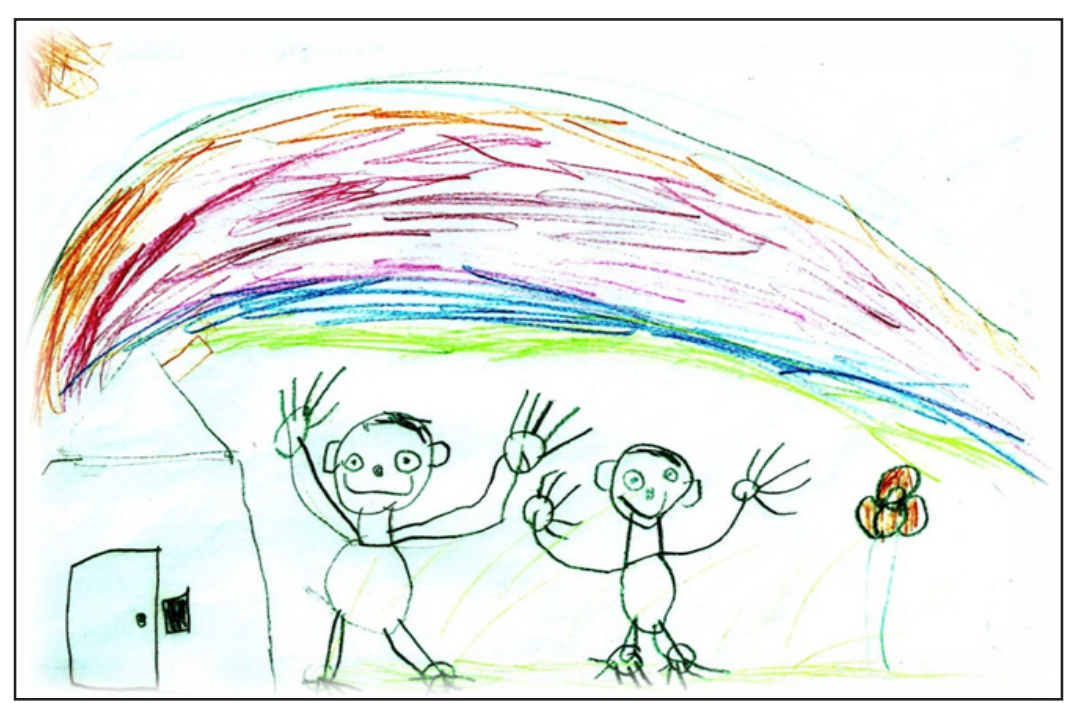

4. ábra: Hatéves fiú rajza saját magáról és óvó bácsijáról

Említésre méltó továbbá az ellentétes nemű szereplőket felvonultató rajzokon a színhasználat által jelzett különbségek figyelembevétele. Ez a szempont fiúk és lányok rajzain egyaránt megjelenik, ugyanakkor, míg a lányok általában a rózsaszín-kék kontrasztot használják, addig a fiúk inkább a piros-kék/zöld színekkel jelzik a különbséget. $A$ rajzokon megfigyelhető továbbá, hogy azokon a nemi különbségeket több esetben is jelölték a figurák fejének rózsaszín vagy kék színü kiemelésével a gyermekek (ld. 5. ábra).

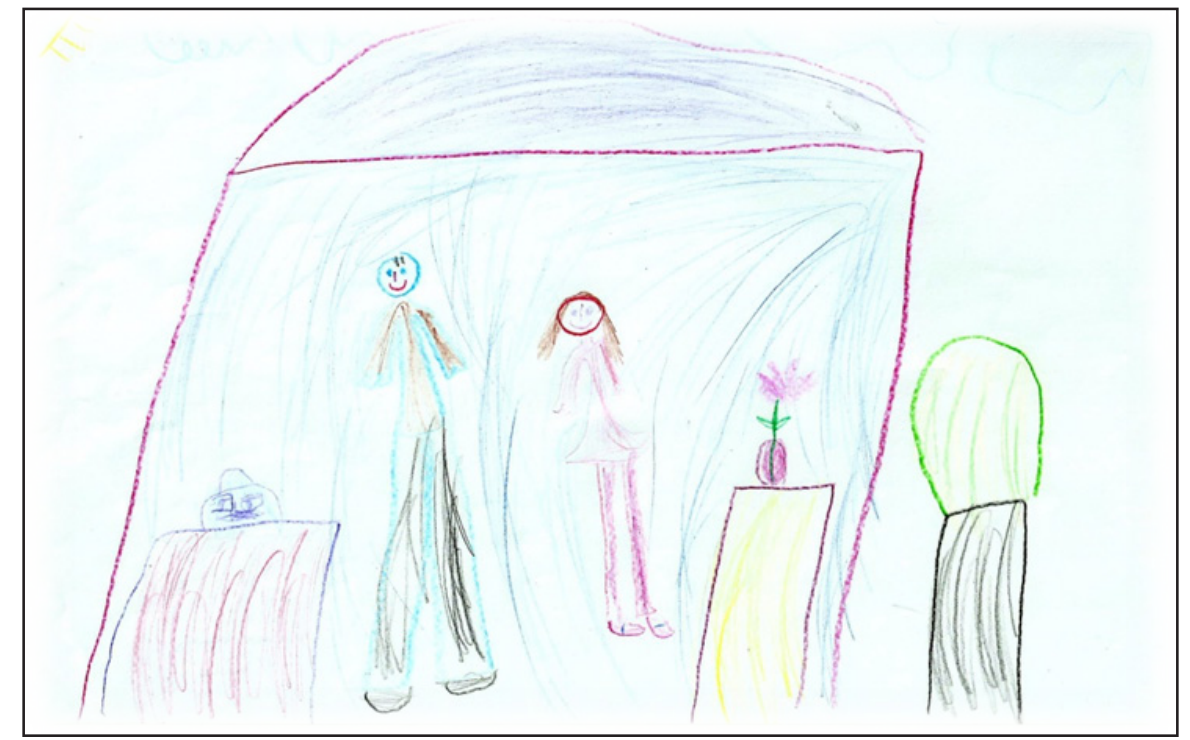

5. ábra: Hatéves lány rajza, amint óvó bácsijával éppen az óvodában játszanak

A vizsgálatban részt vevő gyermekek pedagógusaikhoz fűződő érzelmi viszonyáról, valamint a közöttük fennálló kapcsolatról sokat elárulhat a rajzokon szereplők arckifejezése, testtartása, illetve a figurák közötti interakciók minősége is. Az elkészült 74 rajz közül 60 ábrázol kedves, mosolygós pedagógust, 2 rajzon nem látszik az arckifejezés. 12 rajzon ábrázolták a gyermekek pedagógusaikat morcosnak vagy semlegesnek.

A figurák testtartásukat illetően 60 rajzon megegyezőek, ebből 10 rajzon ábrázolták a gyermekek magukat és pedagógusaikat valamilyen közös miliőben, melyek közül a leggyakoribb a szivárvány általi körbeölelés. A pedagógussal való közös unió 
szeretetkapcsolatra és bizalomra utal, hasonlóan az előbbiekben már említett tevékenység választásokhoz és gazdag színhasználathoz.

Noha a rajzok többségében a pedagógusokkal való azonosulásra elsősorban a hasonló ábrázolásmód és megegyező testtartás utalnak, 10 rajzon konkrét interakciók is megjelennek. Ezen rajzokra az egymás felé forduló testek, a kézfejek összeérése (Id. 6. ábra), a szemkontaktus megléte (Id. 7. ábra), vagy a pedagógusok gyermekek felé hajlása jellemző.

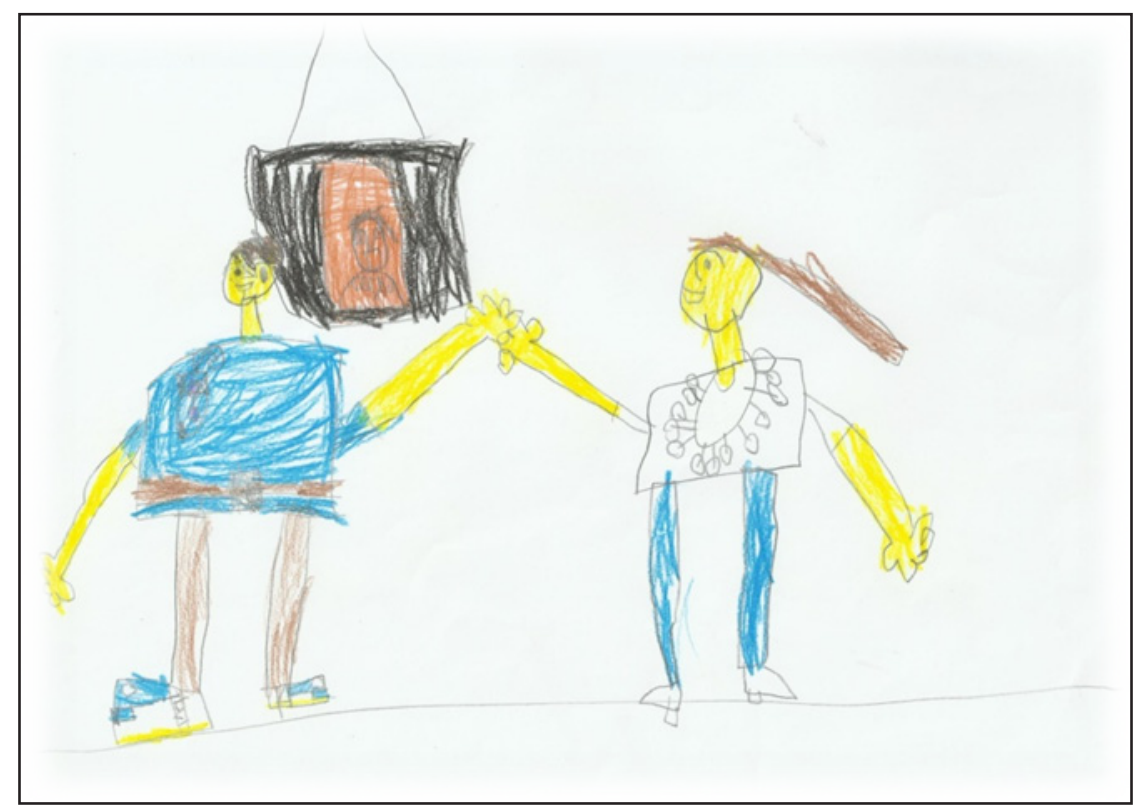

6. ábra: Hatéves fiú rajza, amint óvónőjével a faliújság előtt beszélgetnek

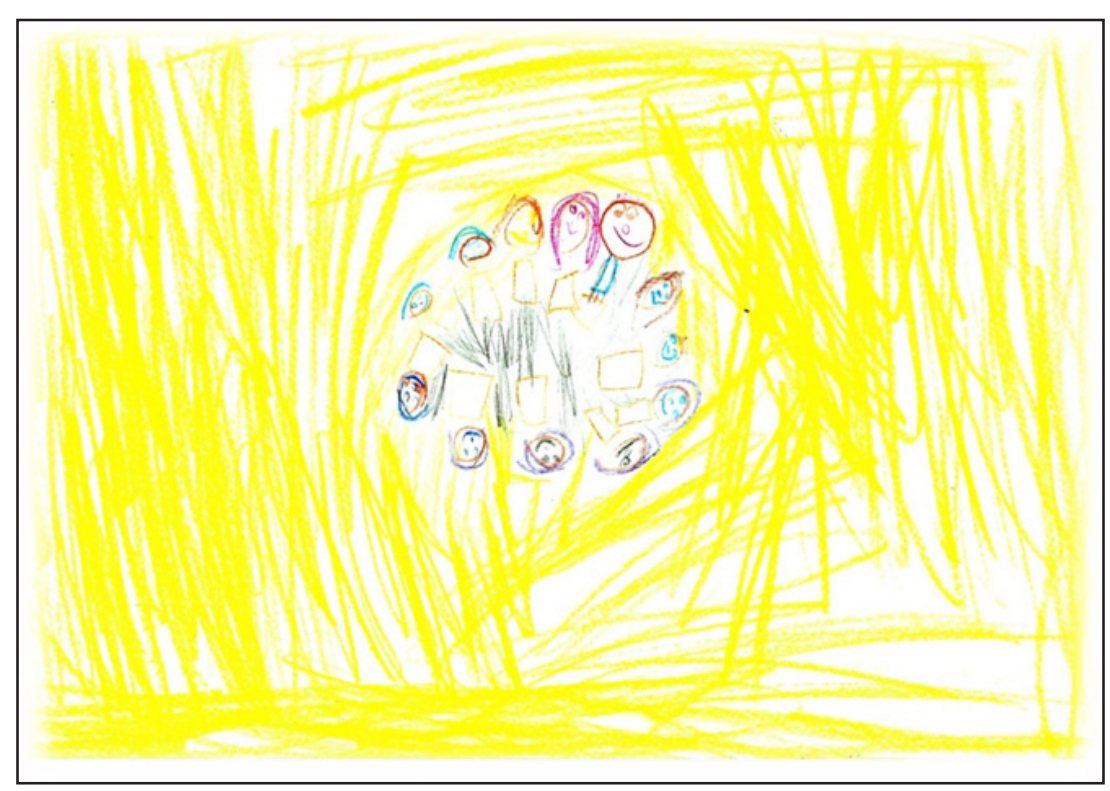

7. ábra: Ötéves lány rajza, amint óvó bácsijával és a többi gyerekkel az asztalnál rajzolnak

A vizsgálatban szereplő rajzok többsége a pozitív pedagógus-gyermek viszony meglétére utal, s az óvodapedagógusokat a gyermekek bizalmát élvező, fontos és szeretetre méltó nevelőkként ábrázolja. A férfi és női pedagógusok közötti, gyermekek által érzékelt különbségeket a rajzok elsősorban a figurák megrajzolásának módjaiban és a színhasználatban, nem pedig az eltérő tevékenységek ábrázolásán keresztül érzékeltetik. 
A metaforamódszer olyan, a pedagógiai kutatások során is alkalmazott kutatási módszer, mely a különböző fogalmakhoz tartozó mélyebb tartalmak feltárását segíti elöhívni (Vámos, 2001). Alkalmazásával elsődleges céljaink közé tartozott a gyermekek fejében az óvodapedagógusokról alkotott kép differenciáltabb felszínre hozása.

A férfi és női pedagógusokra adott metaforákat annak tükrében csoportosítottuk, hogy azok az emberek számára veszélytelen, szelíd, vagy veszélyes vadállatokat jelenítenek-e meg, illetve külön kategóriába helyeztük a békára asszociáló válaszokat, hiszen azok hátterében - a gyermekek elmondásai alapján - minden esetben a mesékből jól ismert átváltozási motívum állt.

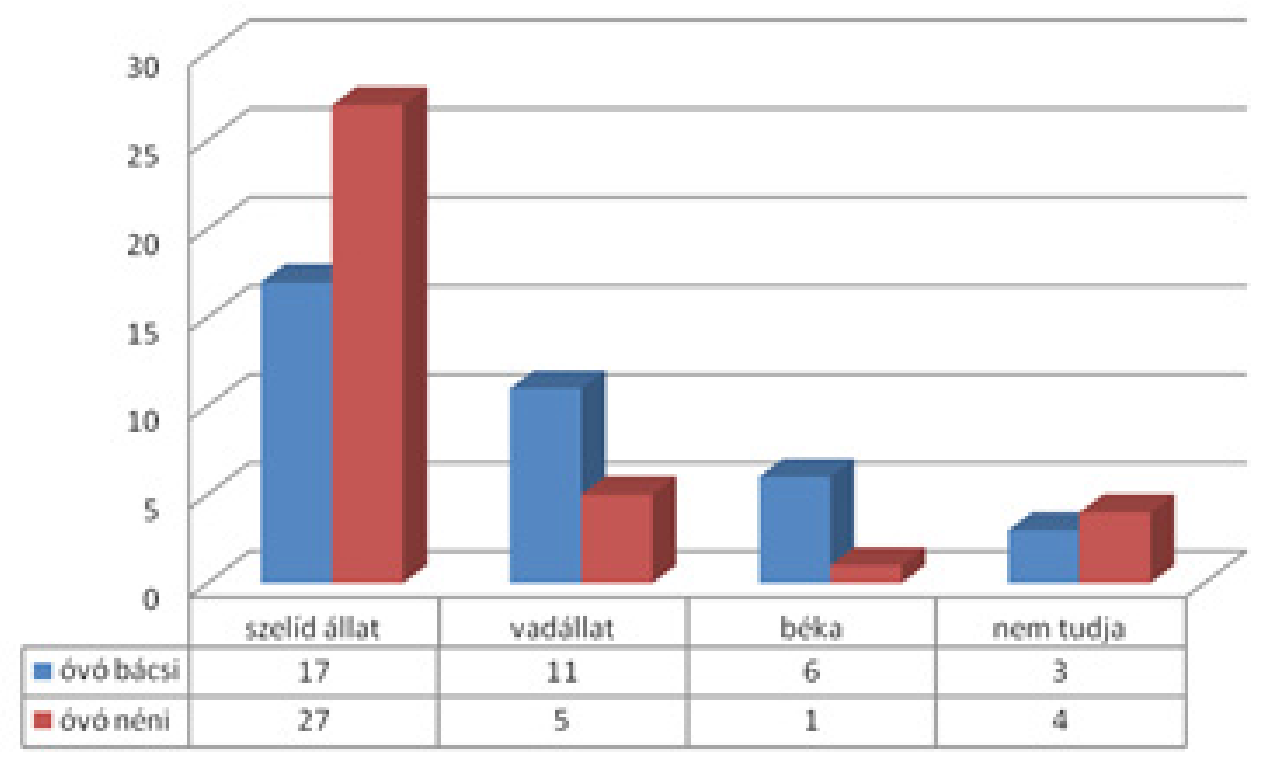

2. diagram: A férfi és női óvodapedagógusokra adott asszociációk megoszlása

A gyermekek asszociációiban szembetűnő különbség figyelhető meg a pedagógusok nemének vonatkozásában. A rögzített válaszokban az óvónők nagyobb arányban változnának szelíd állatokká, mint férfitársaik, akik viszont vadállattá változásaik számában előzik meg őket. Ez a különbség egyszerre utalhat az óvó bácsik nagyobb tekintélyére, félelmetesebb, szigorúbb kisugárzására, illetve az óvónőknek - az anyai szerephez hasonló - gondoskodó jellegére is. Eltérés figyelhető meg továbbá a tekintetben is, hogy az óvó bácsikat gyakrabban azonosítják a gyermekek a nagytestü, férfias állatokkal, úgymint bálna, gorilla, gepárd, leopárd, tigris, farkas vagy oroszlán, míg az óvónőkről legtöbb esetben a kecses gazellára, őzre, zsiráfra, a szintén inkább nőies tulajdonságokkal rendelkező macskára és bárányra, vagy az apró termetü, gyenge pillangóra és katicabogárra asszociáltak. A kutya mint az ember leghűségesebb társa és legjobb barátja egyenlő arányban fordult elő a két nem tekintetében, a mókás kisugárzású, ritkább állatokat - pingvin, kenguru - azonban szintén az óvó bácsik személyével feleltették meg a gyermekek.

\section{Az óvodapedagógusok óvodai életben betöltött szerepe}

Az óvók feladatát a megkérdezett gyermekek különböző tényezők mentén határozták meg, válaszaikban pedig különbség tehető a tekintetben, hogy óvó nénikkel, vagy óvó bácsikkal kapcsolatban nyilatkoztak (Id. 3. diagram). 


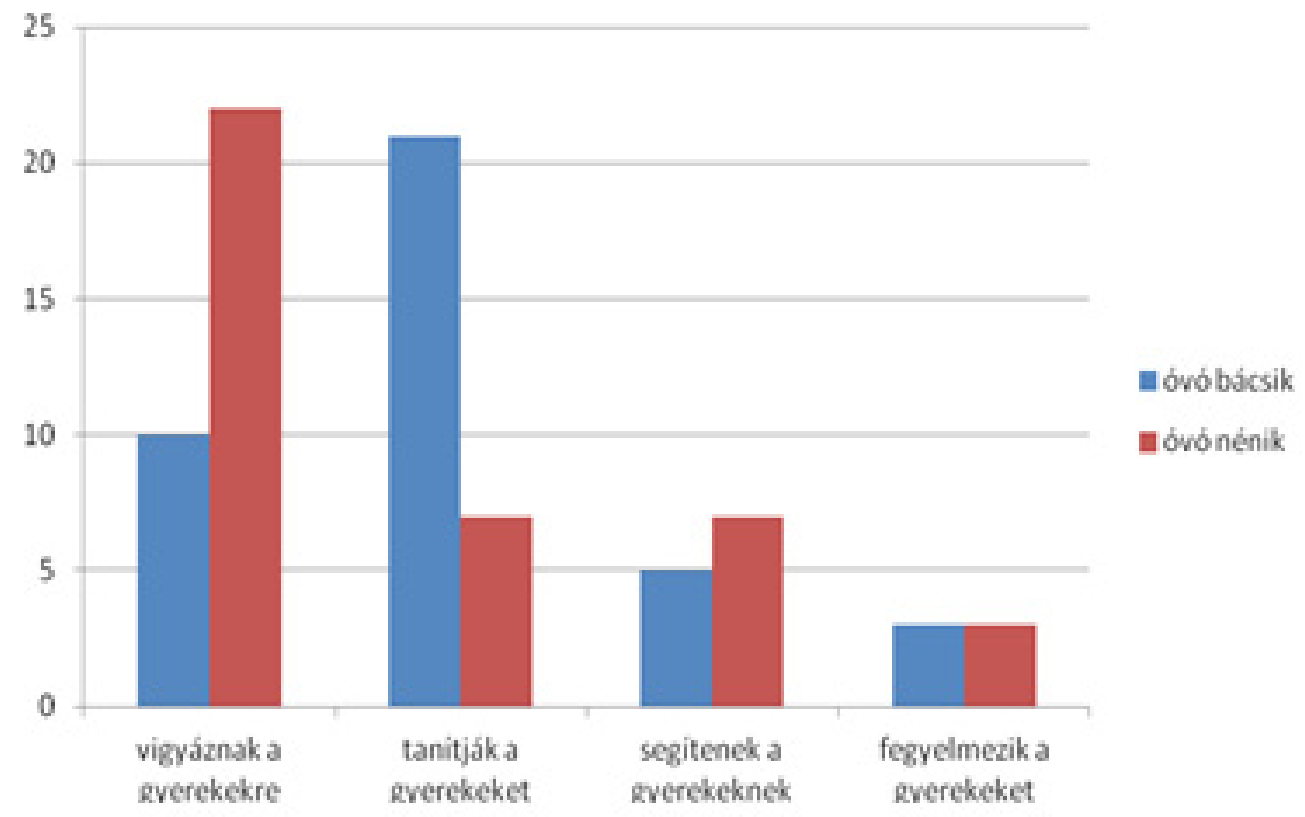

3. diagram: Az óvodapedagógusok feladatai az óvodában

A megkérdezett gyermekek szerint az óvóknak elsősorban az óvodás korú gyermekek felügyelete, illetve tanítása a feladatuk, ezen belül elmondható, hogy az óvónőktől a gyermekek elsősorban a rájuk való vigyázást, míg a férfi óvodapedagógusoktól az új ismeretek átadását várják. $E$ tekintetben elkülönülni látszik egymástól a nők gondoskodó és a férfiak tanító jellegű pedagógusi szerepe, amit a kutatás további eredményei is megerősítenek majd. Mindezek mellett - a gyermekek válaszai szerint - az óvodapedagógusi szereppel összetartozó feladat az óvodások különböző helyzetekben való segítése és fegyelmezése. A segítségnyújtást elsősorban konfliktushelyzetek megoldásában, és életkorukból fakadó akadályozottságuk esetén várják, de megjelent a válaszok között a tanácstalanságban történő ötletadás is, például játéktevékenység ajánlása. A fegyelmezést elmondásuk alapján azért tartják fontosnak a gyermekek, mert általa elkerülhetővé válnak a balestek és felesleges veszekedések.

\section{Az ideális óvodapedagógus jellemzői}

\begin{tabular}{|lcc|}
\hline AZ IDEÁLIS ÓVODAPEDAGÓGUS & \\
\hline Megnevezett tulajdonságok & Óvónők & Óvó bácsik \\
\hline Kedves, aranyos & $33 \%$ & $27 \%$ \\
\hline Szereti a gyerekeket & $13 \%$ & $6 \%$ \\
\hline Segítőkész & $10 \%$ & $7 \%$ \\
\hline Saját pedagógussal megegyező & $10 \%$ & - \\
\hline Vicces & - & $9 \%$ \\
\hline Sokat játszik a gyerekekkel & $7 \%$ & $16 \%$ \\
\hline Fegyelmezi a gyerekeket & $5 \%$ & $6 \%$ \\
\hline Gondoskodó & $5 \%$ & $5 \%$ \\
\hline Jó ötletei vannak & $3 \%$ & \\
\hline
\end{tabular}




\begin{tabular}{|lcc|}
\hline Sokat foglalkozik a gyerekekkel (mesél, rajzol...) & $3 \%$ & $9 \%$ \\
\hline Kibékíti a gyerekeket, ha összevesznek & $3 \%$ & - \\
\hline Okos & $2 \%$ & $4 \%$ \\
\hline Sok mindent megtanít & $2 \%$ & $7 \%$ \\
\hline Jószívü & $2 \%$ & $1 \%$ \\
\hline Megérti, amit a gyerekek mondanak neki & $2 \%$ & - \\
\hline Mindent észben tart & - & $1 \%$ \\
\hline
\end{tabular}

1. táblázat: Az ideális óvodapedagógus jellemzői a megkérdezett gyermekek szerint

Az óvodáskorú gyermekek pedagógusképének feltárásakor nélkülözhetetlen annak vizsgálata, vajon mi jellemzi a gyermekek által ideálisnak tartott, jó óvodapedagógust, akinek csoportjába nap mint nap szívesen érkezne minden óvodás. A résztvevők e kérdésre adott válaszainak összesítését és egyúttal a gyermekek által ideálisnak tartott pedagógus jellemzőit az 1. táblázat tartalmazza.

Annak minél látványosabb érzékeltetése érdekében, hogy mely tulajdonságokat említették a gyermekek jellemzően női, melyeket pedig inkább férfi óvodapedagógusokkal kapcsolatban, a táblázatban különböző színeket használtunk: a pirossal kiemelt tulajdonságokat lényegesen több gyermek említette a jó óvónő, míg a kékkel jelzettek a jó óvó bácsi jellemzőjeként. Ez alapján elmondható, hogy míg az óvónők kívánatos tulajdonságai között inkább a gondoskodó attitűd jegyei - kedves, segítőkész, szereti a gyerekeket, gondoskodik a gyerekekről - fedezhetőek fel, addig a férfiaktól másfajta pedagógusi szerepet várnak a gyerekek, melyben a minél több közösen végzett tevékenység, a humor, és a pedagógustól való tanulás lehetősége válik meghatározóvá.

Megemlítendő, hogy a megkérdezett gyermekek 10\%-a azonosítja a jó pedagógust saját óvónőjének személyével, ami a közöttük fennálló szeretetkapcsolatra utal. A gyermekek szeretete pedig - jelen kutatás eredményei szerint is - egyike a jó pedagógus ismérveinek.

\section{A nemkívánatos óvodapedagógus jellemzői}

Kutatásunkban az ideális óvodapedagógus ismérveinek összegyűjtésén túl arról is megkérdeztük a gyermekeket, mi jellemezné azokat a pedagógusokat, akiknek csoportjába nem szívesen járnának. Ahhoz ugyanis, hogy teljes képet kapjunk a gyermekek óvodapedagógusok személyével kapcsolatban meglévő gondolataikról és velük szemben támasztott igényeikről, azt is indokolt vizsgálni, milyen tulajdonságokkal jellemeznek egy véleményük szerint kevésbé jó pedagógust. A gyermekek válaszait az alábbi, 2. táblázat foglalja össze:

\begin{tabular}{|lcc|}
\hline A NEMKIVÁNATOS ÓVODAPEDAGÓGUS JELLEMZÖI & & \\
\hline Megnevezett tulajdonságok & Óvónők & Óvó bácsik \\
\hline Szigorú (nem enged meg semmit, mindenért szól...) & $33 \%$ & $12 \%$ \\
\hline Kiabál & $20 \%$ & $18 \%$ \\
\hline Gonosz (eltépi a rajzokat, nem ad enni...) & $13 \%$ & $18 \%$ \\
\hline Nem foglalkozik a gyerekekkel & $7 \%$ & - \\
\hline Nem segít semmiben & $7 \%$ & $2 \%$ \\
\hline Nem kedves & $4 \%$ & $2 \%$ \\
\hline
\end{tabular}


Óvó nénik és óvó bácsik - ahogyan a gyerekek látják őket

\begin{tabular}{|lcc|}
\hline Mindig mérges & $3 \%$ & $13 \%$ \\
\hline Rosszkedvű & $3 \%$ & - \\
\hline Nem beszél a gyerekekhez & $2 \%$ & - \\
\hline Nem vigyáz a gyerekekre & $1 \%$ & $3 \%$ \\
\hline Nem szeretget & $1 \%$ & - \\
\hline Nincs rossz pedagógus & $4 \%$ & $3 \%$ \\
\hline Nem játszik a gyerekekkel & - & $15 \%$ \\
\hline Bánt (megüt, megver...) & - & $12 \%$ \\
\hline Nem érti a gyerekeket & - & $2 \%$ \\
\hline
\end{tabular}

2. táblázat: A nemkívánatos pedagógus jellemzői a megkérdezett gyermekek szerint

A kevésbé jó pedagógusok tulajdonságainak meghatározása nem volt egyszerü feladat a gyermekek számára, és a válaszadás is több időt vett igénybe, mint amikor a jó pedagógust definiálták. Ennek két oka lehet: egyrészről ahogyan azt a rajz- és metaforavizsgálat összevetésekor is láthattuk, a gyermekek nehezen fogalmazzák meg negatív élményeiket, másrészről pedig feltételezhetjük, hogy a megkérdezett gyermekek többségét szerencsére olyan pedagógusok veszik körül, akik szeretik őket. Élményvezérelt gondolkodásukból fakadóan így kevesebb negatív történést tudnak elöhívni, ami egyúttal nehezítheti a nemkívánatos pedagógusi személyiségjegyek öszszegyűjtését is.

A válaszok összesítését figyelembe véve - melyeket az 1. táblázatban alkalmazott módszerrel megegyezően differenciáltunk a döntően férfi vagy női pedagógusokkal kapcsolatban elhangzottak jelölése céljából - megállapítható, hogy a gyermekek óvónőkről és óvó bácsikról alkotott pedagógusképe e tekintetben is eltérést mutat, noha a kiabálósság mindkét esetben egyike a legelvetendőbb tulajdonságoknak. Míg egy rossz óvó nénit elsősorban a gyermekek iránti szeretetének megvonása, a segítségnyújtás megtagadása jellemez, addig a gyermekek elképzelhetőnek tartják, hogy a rossz óvó bácsi tettlegesen bántaná a gyerekeket, és szintén kézzel fogható gonosz cselekedeteket hajtana végre - pl. összetépi a gyermekek rajzait, vagy lerombolja a megépített várakat.

A negatív tulajdonságok mentén kirajzolódó kép összhangban áll az összegyűjtött kívánatos jegyek eredményeivel, miszerint a gyermekek számára az óvónők testesítik meg a lágyabb, gondoskodóbb nevelőt, míg az óvó bácsik a mindennapokban is jellemző, férfiasnak mondható jegyeket hordozzák.

\section{A férfi és női óvodapedagógusok közötti különbségek}

A kutatás mintáját figyelembe véve eltérő válaszok születtek a férfi és női óvodapedagógus közötti különbségekkel kapcsolatban, aszerint, hogy a megkérdezett gyermeknek van-e óvó bácsija is, vagy nem. 


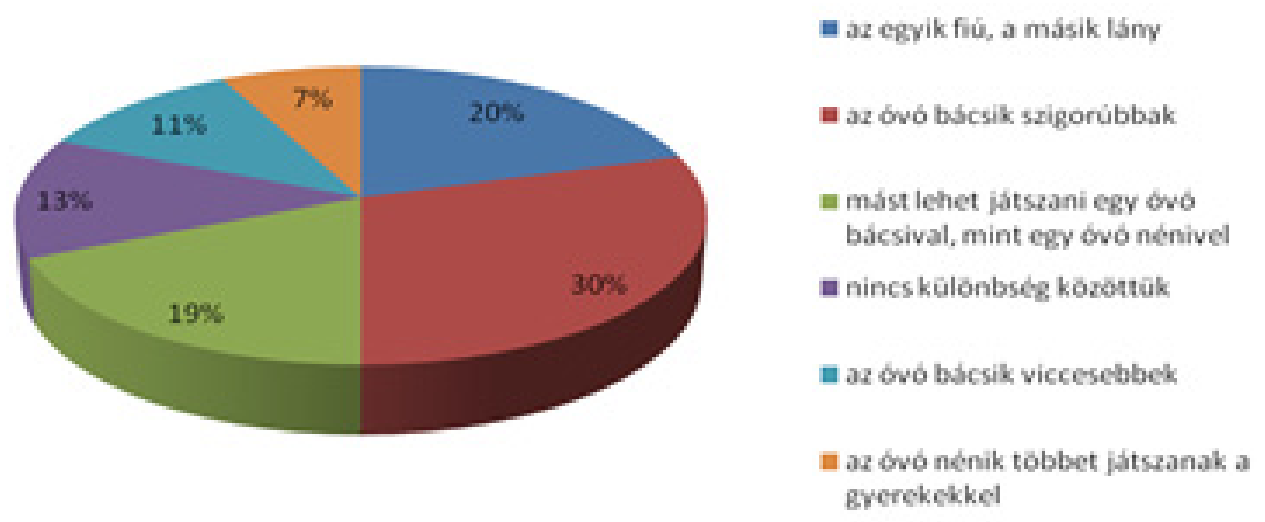

4. diagram: A férfi és női óvodapedagógusok közötti különbségek a csak óvónővel bíró gyermekek szerint

Ahogyan a 4. diagramból is leolvasható, azok a gyermekek, akik még nem találkoztak óvodai csoportjukban férfi pedagógusokkal, túlnyomó részt (16 fö) azt gondolják, hogy az óvó bácsik szigorúbbak az óvónőknél, ahogyan az a tendencia is megjelenik válaszaikban, miszerint az óvónőkkel többet lehet játszani, mint az óvó bácsikkal.

A megkérdezettek közül többen (10 fő) azt feltételezik, hogy másfajta játékokat lehet játszani egy óvó bácsival, mint egy óvó nénivel; a válaszokban leggyakrabban előforduló ilyen jellegű tevékenységek a társasjátékozás, legózás, focizás és egyéb mozgásos játékok voltak. Megemlítendő, hogy míg az óvó bácsik szigorúságáról általában lányok számoltak be, addig a változatos tevékenységek lehetőségét elsősorban fiúk emelték ki.

11 gyermek nevezte meg különbségként a pedagógusok nemét, 7 gyermek pedig nem tudott eltérést megfogalmazni a férfi és női óvodapedagógusok között.

Az óvó bácsik csoportjába járó gyermekek válaszainak megoszlását az alábbi, 5 . diagram foglalja össze:
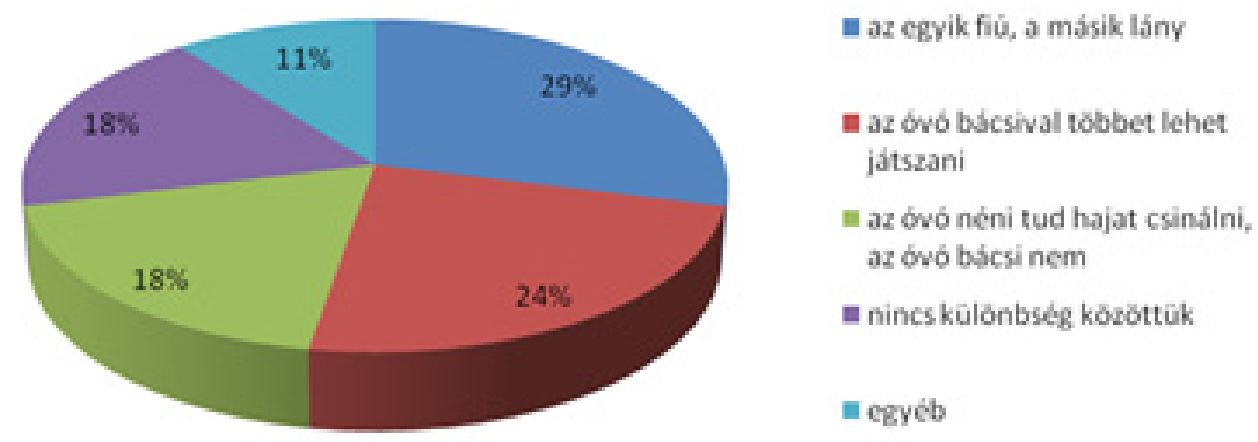

5. diagram: A férfi és női óvodapedagógusok közötti különbségek az óvó bácsival is bíró gyermekek szerint

Az óvó bácsikról saját tapasztalattal is bíró gyermekek válaszaiban nagyobb arányban fordult elő az „egyik fiú, a másik lány” válaszkategória a különböző kategóriák egymáshoz viszonyított százalékos megoszlását illetően, ugyanakkor ebben az esetben is 11 gyermek fogalmazta meg ezt. Eltérés mutatkozott azonban a megkérdezett gyermekek másik csoportjához képest abból a szempontból, hogy ezek a gyerekek jobban meg tudták fogalmazni a nemi eltérésből adódó olyan különbségeket, mint 
az erő, a magasság, a hajhosszúság. A válaszaikhoz társított példákat - úgymint „az óvó bácsi erősebb, mert ha az óvó néni nem bír el valamit, akkor az óvó bácsi cipeli helyette" - a gyermekek saját tapasztalataikból merítették, ezzel is bizonyítva élményvezérelt gondolkodásuk tökéletes müködését.

Szembetűnő különbség továbbá a két gyermekcsoport válaszai között, hogy a szigorúság mint az óvó bácsik egyik fő jellemzője a személyes tapasztalatokkal is rendelkező gyermekek válaszaiban egyáltalán nem jelent meg, ami - hasonlóan a nemkívánatos óvó bácsik jellemzésekor megjelenő tulajdonságok egy részéhez - a társadalomban meglévő, s jelen kutatás szerint a gyermekekre is hatást gyakorló, különböző nemi szerepekkel kapcsolatos sztereotípiákra utal.

Az óvó bácsival is bíró gyermekek 24\%-a, azaz 9 fö jegyezte meg, hogy a férfi pedagógusokkal többet lehet játszani, ahogyan az ideális óvó bácsi jellemzői között is - ellenétben a jó óvónő legfontosabb tulajdonságaival - nagy arányban képviseltette magát a közös tevékenységek végzésének lehetősége.

6 kislány és 1 kisfiú említette különbségként az óvó bácsikból hiányzó frizurakészítő képességet, ami szintén az élményvezérelt gondolkodásra utal. Szintén az e típusú gondolkodásmódot sejteti, hogy 7 gyermek - hasonlóan a másik csoport válaszaihoz - nem tudott eltéréseket megfogalmazni. Véleményük szerint az óvó bácsik és az óvó nénik ugyanazokat a dalokat és verseket tanítják, és egyformán kedvesek.

Az 5. diagramon látható „egyéb” kategóriába négy gyermek válasza tartozik, akik különbségként olyan egyéni jegyeket fogalmaztak meg, mint a más színű szem, vagy a karóra viselésének ténye.

A strukturált interjú zárásaként arról kérdeztük a kizárólag óvónők csoportjába járó gyermekeket, örülnének-e, ha nemcsak óvó nénijük, de óvó bácsijuk is lenne, és miért. A kapott eredményekben eltérés figyelhető meg aszerint, hogy fiúk vagy lányok voltak a kérdésre válaszolók.

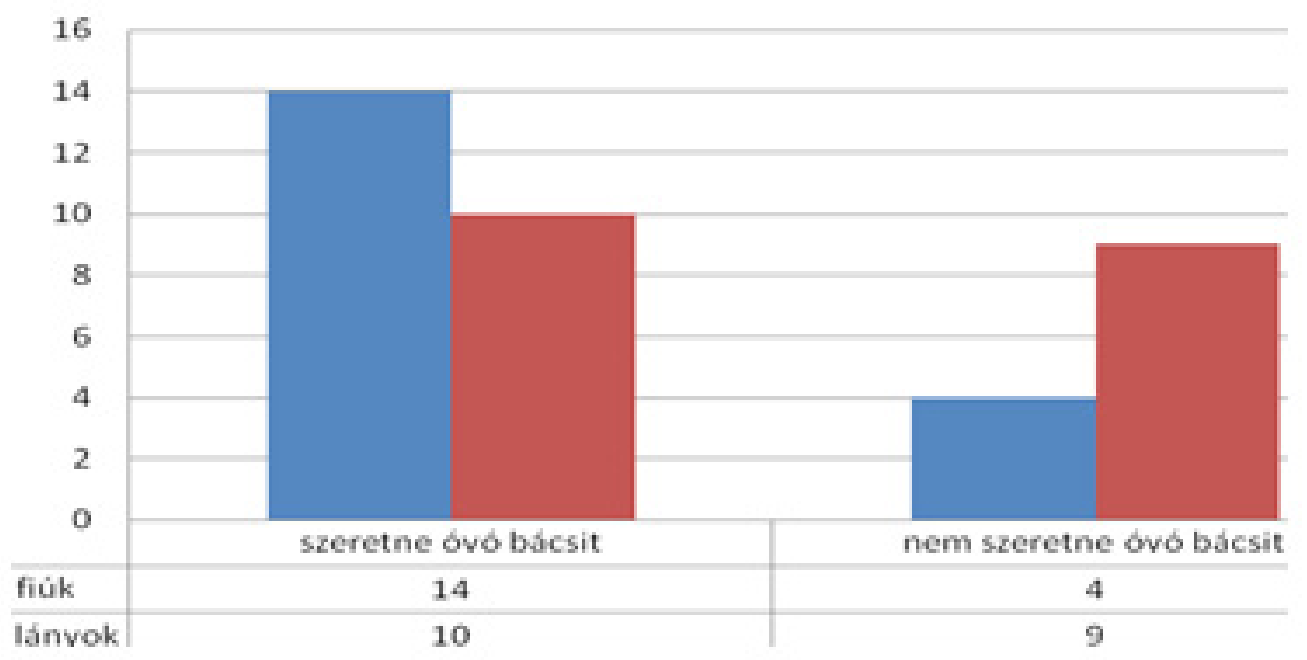

6. diagram: A férfi óvodapedagógussal nem bíró gyermekek véleményének megoszlása a tekintetben, hogy szeretnének e saját óvó bácsit

Összességében elmondható, hogy a megkérdezett fiúk többsége örülne annak, ha csoportjában óvó bácsi is dolgozna, elsősorban azért, mert velük más típusú játéktevékenységeket is lehetne folytatni. Ezzel szemben a megkérdezett lányoknak körülbelül a fele örülne egy óvó bácsinak, míg másik felük elzárkózik tölük. Az óvó bácsik elutasításának egyetlen megfogalmazott oka - a fiúk válaszainak esetében is - a vélt 
szigortól való félelem, amit többen saját édesapjukról való benyomásaikra hivatkozva jelentettek ki.

Érdekes különbség továbbá, hogy míg a fiúk a közös, inkább fiúsnak mondható játéktevékenységek végzését tulajdonítják az óvó bácsik egyik fő erősségének, addig a lányok elsősorban azért örülnének a férfi óvóknak, mert akkor az óvónőkön kívül eggyel több, róluk gondoskodó személyt tudhatnának maguk körül.

\section{Összegzés, az eredmények értelmezése}

Az óvodáskorú gyermekek pedagógusképét feltárni kívánó kutatásunk során kapott eredményeket figyelembe véve megállapítható, hogy a megkérdezett gyermekek túlnyomó többségét bizalmas szeretetkapcsolat füzi óvodapedagógusaihoz. A kapott válaszokból kitűnik, hogy az óvodások általános pedagógusképének alakulását erősen befolyásolják a saját pedagógusaikkal kapcsolatban meglévő benyomásaik, melyeket elsősorban személyes tapasztalataik és élményeik által alakítanak ki. Ez azt eredményezi, hogy az óvodások általános pedagógusképe többnyire megegyezik a saját pedagógusaikról kialakult képükkel.

A kutatás elején felállított hipotéziseket tekintve elmondható, hogy az 1. előfeltevésünk - miszerint a szakirodalomban megjelenő pedagógusi kompetenciák nagyjából megegyeznek a gyermekek által kedvelt pedagógus személyiségjegyeivel - helytállónak bizonyult. Noha a megkérdezett óvodások életkori sajátosságaikból, valamint nyelvi és gondolkodásbeli fejlettségükből adódóan eltérő módokon fogalmazták meg a szakirodalomban foglaltakat, mondanivalójuk hátterében a szakirodalom által is fontosnak vélt motívumok húzódnak meg.

A gyermekek által első helyen említett kedvesség és gyermekszeretet alapvetően határozzák meg a pedagógus bizalomteli légkör megteremtésére irányuló képességét, ahogyan a segítőkészség, mint a gyermekek által szintén fontosnak gondolt pedagógusi tulajdonság egyúttal feltételezi a jó helyzetfelismerési és empátiás képességet is. A gyermekek között adódó nézeteltérések megoldásában az óvodapedagógus jó konfliktuskezelő képességére is szükség van, továbbá nem hanyagolható el a kreativitás szükségessége sem, amit a gyermekek úgy fogalmaztak meg, hogy a jó óvónak mindig jó ötletei vannak. A szakirodalomban megfogalmazott játszani tudás képessége a gyermekek válaszait figyelembe véve talán egyike a legmeghatározóbb óvodapedagógusi kompetenciáknak, hiszen a játék önmagában is az óvodai élet legmeghatározóbb tevékenysége - láthattuk, hogy a megkérdezett gyermekek jelentős hányada az óvodába járás okát is a sokszínü játéktevékenység lehetőségével kapcsolja össze. A pedagógussal végzett közös tevékenységek - beleértve az előbb említett játékot is - a gyermekek számára kiemelt jelentőséggel bírnak, s a pedagógustól az előbb említett képességek meglétén túl egyaránt várnak el kommunikációs ügyességet, magas szintű szervezőképességet, valamint szaktudást.

A 2. hipotézis - miszerint az óvodáskorú gyermekek különbséget tesznek a férfi és női óvodapedagógusok között, és az eltéréseket meg is tudják fogalmazni - helytállóságát illetően elmondható, hogy bár a megkérdezett gyermekek többsége valóban észleli különbséget óvó bácsik és óvó nénik között a csak óvónővel bíró gyermekek $13 \%$-a, az óvó bácsival is bírók 18\%-a nem tudott közöttük eltéréseket megfogalmazni. Ahogyan azt az eredmények részletes ismertetéskor is említettük, a gyermekek válaszaiban legtöbbször a pedagógusok eltérő neme („az egyik fiú, a másik lány”) mint fennálló különbség jelent meg, de eltérés mutatkozott a férfi és női pedagógusokkal való közös játéktevékenységek gyakoriságát és jellegét illetően is. 
A kapott válaszok tükrében elmondható, hogy a gyermekek az óvónőket elsősorban azok kedves, gondoskodó attitüdje, míg az óvó bácsikat inkább a velük végezhető közös tevékenységek miatt kedvelik, a 3. hipotézisben foglaltakkal megegyezően. Nem helytálló ugyanakkor az előfeltevés azon része, miszerint az óvónőkkel szemben táplált rokonszenvet erősen meghatározza a vonzó fizikai külső, ugyanis a szépség az ideális óvodapedagógus jegyei között egyáltalán nem jelent meg, a megkérdezett gyermekek közül pedig mindössze heten emelték ki azt, saját óvónőikkel kapcsolatban.

A 4. hipotézisben megfogalmazottak igaznak bizonyultak, hiszen azon gyermekek többsége, akinek nincs férfi óvodapedagógusa örülne, ha lenne óvó bácsija is. Érdekes eredmény ugyanakkor, hogy a megkérdezett gyermekek közül elsősorban a fiúk szeretnének óvó bácsit is, az óvónőkkel közösen nem végezhető játéktevékenységek miatt - úgymint focizás, legózás. A lányok többsége tart a férfi óvodapedagógusoktól, véleményük szerint ugyanis azok feltehetően szigorúbbak lennének az óvónőknél, ahogyan az apukák is szigorúbbak az anyukáknál.

Összességében elmondható, hogy a gyermekek másfajta, ám egyformán fontos pedagógusi szerepet várnak el a férfi és női óvodapedagógusoktól. Ahogyan az a témával kapcsolatos szakirodalmakban is olvasható, az óvónők elsősorban a valós életből vett kedves és gondoskodó anya-, míg az óvó bácsik inkább a sokszor vicces és rengeteg új dologra tanító apamodellt állítják az óvodáskorú gyermekek elé. Nem lehet kérdés, hogy óvónőkre és óvó bácsikra egyaránt szükség van az óvodai nevelés során, különösen azon gyermekek esetében, akik csonka családokban kényszerülnek felnőni.

\section{Irodalom}

Bilibok Péterné, Sebestyén Istvánné és Zibolen Endre (1984): Első óvodáink életéből. Tankönyvkiadó, Budapest.

Fábián Gyöngyi (2011): Tükörtöl tükörig. A pedagógus pályakép változásainak elmúlt negyven éve. Iskolakultúra, 21. 12. sz. 10-22.

Fehér Veronika (2000): Az óvodapedagógus mint segítő. In: Micheller Magdolna (szerk.): Körös tanulmányok. TSF Körös Föiskolai Kar, Szarvas. 285294.

Fehér Veronika (2003): A pedagógus kívánatos személyiségjegyei a 21. században. In: Virágné Horváth Erzsébet (szerk.): Diskurzus. Tudomány és müvészet. Tessedik Sámuel Főiskola Pedagógiai Föiskola Kar, Szarvas. 33-45.

Hegyi Ildikó (1996): Siker és kudarc a pedagógus munkájában. A pedagógiai képességek és fejlesztésük módjai. OKKER Kiadó, Budapest.

Jávorné Kolozsváry Judit (2004): Az óvodapedagógus személyisége. In: Jávorné Kolozsváry Judit (szerk.): Az óvodapedagógusi szerep kihívásai. Trezor Kiadó, Budapest. 39-59.

Kovács Edina (2011): A tanári identitás alakulása a társadalmi nemi szerepek tükrében. In. Kéri Katalin (szerk.): Társadalmi nem és oktatás. Konferenciakötet. PTE BTK „Oktatás és társadalom" Neveléstudományi Doktori Iskola, Pécs. http://digitalia.tudaskozpont-pecs.hu/ books/keri-katalin-szerk-tarsadalmi-nem-es-oktatas-2011/htm/kovacsedina.htm (Letöltés ideje: 2015. március 01. 15.32)

Kovács Mónika (2007): Nemi sztereotípiák, nemi ideológiák és karrier aspirációk. Educatio, 16. 1. sz. 99-114.

Kovácsné Bakosi Éva (2008): A játszóképesség, mint a kisgyermekekkel foglalkozók kulcskompetenciája. Debreceni Egyetem Hajdúböszörményi Pedagógiai Főiskolai Kar, Hajdúböszörmény.

Kövér Sándorné (1996): Óvóképzésünk múltjának néhány mának szóló tanulsága. Pedagógusképzés, 1-2. sz. 44-58. 
Kraffszky József (1993): A kisdedóvás és Frőbel kisdednevelési rendszere (1892.). In: Ruzsányiné Dr. HAJZER SzERÉn (SZERK.): I. Szöveggyüjtemény. A magyar óvodai nevelés történetének tanulmányozásához az első óvodától a felszabadulásig. Nemzeti Tankönyvkiadó, Budapest. 57-63.

Perlai Rezsőné (2009): Férfipedagógusok az óvodában. Óvodai Nevelés, 62. 3. sz. 91-92.

Sallai Éva (1996): Tanulható-e a pedagógus mesterség? Veszprémi Egyetemi Kiadó, Veszprém.

Sántha Kálmán (2006): Történeti áttekintés a 20. századi pedagóguskutatásról. Neveléstörténet, 3. 1-2. sz.

Winnicott, D. W. (2000): Kisgyermek, család, külvilág. Animula Kiadó, Budapest.

Vámos Ágnes (2001): A metafora felhasználása a pedagógiai fogalmak tartalmának vizsgálatában. Magyar Pedagógia, 101. 1. sz. 85-108.

Tihanyiné Vályi Zsuzsa (2008): Amiröl a gyermekrajzok beszélnek. JATEPress Kiadó, Szeged. Vass Zoltán és Perger Mónika (2011): A kinetikus iskolarajz. ELTE Eötvös Kiadó, Budapest. 